
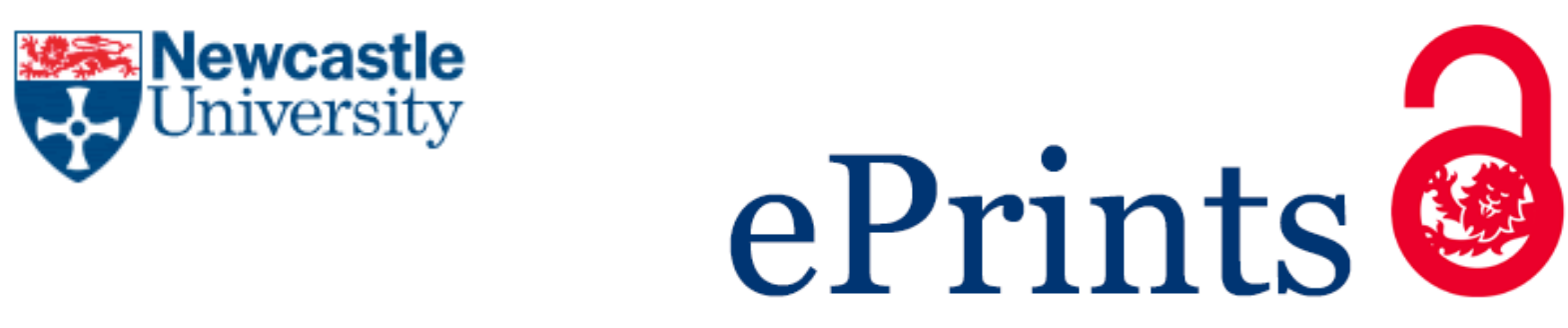

Lewis JP, Ryves DB, Rasmussen P, Olsen J, Knudsen KL, Andersen SH, Weckström K, Clarke AL, Andrén E, Juggins $S$.

The shellfish enigma across the Mesolithic-Neolithic transition in southern

Scandinavia.

Quaternary Science Reviews 2016, 151, 315-320.

\title{
Copyright:
}

(C) 2016. This manuscript version is made available under the CC-BY-NC-ND 4.0 license

DOI link to article:

http://dx.doi.org/10.1016/j.quascirev.2016.09.004

Date deposited:

$12 / 04 / 2017$

Embargo release date:

14 September 2017

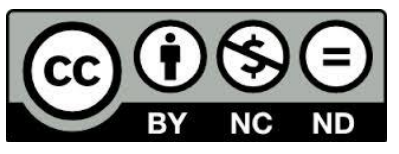

This work is licensed under a

Creative Commons Attribution-NonCommercial-NoDerivatives 4.0 International licence 


\section{The shellfish enigma across the Mesolithic-Neolithic transition in southern Scandinavia}

Lewis, J.P. ${ }^{1 *}$, Ryves, D.B. ${ }^{1}$, Rasmussen, P. ${ }^{2,3}$, Olsen, J. ${ }^{4}$, Knudsen, K.-L. ${ }^{5}$, Andersen, S.H. ${ }^{6}$, Weckström, K. ${ }^{3}$, Clarke, A.L. ${ }^{7}$, Andrén, E. ${ }^{8}$ and Juggins, S. ${ }^{9}$

${ }^{1}$ Centre for Hydrological and Ecosystem Science, Department of Geography, Loughborough University, Loughborough LE11 3TU, UK.

${ }^{2}$ Environmental Archaeology and Materials Science, National Museum of Denmark, I.C. Modewegsvej, DK-2800 Kgs. Lyngby, Denmark.

${ }^{3}$ Department of Marine Geology and Glaciology, Geological Survey of Denmark and Greenland (GEUS), Øster Voldgade 10, DK-1350 Copenhagen K, Denmark.

${ }^{4}$ Department of Physics and Astronomy, Aarhus University, Ny Munkegade 120, DK-8000 Aarhus C, Denmark.

${ }^{5}$ Department of Earth Science, Aarhus University, Høegh-Guldbergs Gade 2, DK-8000 Aarhus C, Denmark.

${ }^{6}$ Moesgård Museum, DK-8270 Højbjerg, Denmark.

${ }^{7}$ APEM Aquatic Scientists Ltd, Riverview, A17 Embankment Business Park, Stockport, SK4 3GN, UK

${ }^{8}$ School of Natural Sciences, Technology and Environmental Studies, Södertön University, SE-141 89 Huddinge, Sweden.

${ }^{9}$ School of Geography, Politics and Sociology, Newcastle University, Newcastle upon Tyne NE1 7RU, UK.

*Corresponding author (J.P.Lewis@lboro.ac.uk) 


\section{Abstract}

The well-known and widespread replacement of oysters (abundant during the Mesolithic period) by cockles and mussels in many Danish Stone Age shell middens ca. 5,900 cal. yrs BP coincides with the transition to agriculture in southern Scandinavia. This human resource shift is commonly believed to reflect changing resource availability, driven by environmental and/or climatic change at the Mesolithic-Neolithic transition rather than cultural choice. While several hypotheses have been proposed to explain the "Mesolithic-Neolithic oyster decline", an explanation based on a sudden freshening of the inner Danish waters has received most attention. Here, for the first time, we test and refute this long-standing hypothesis that declining salinity explains the marked reduction in oysters identified within numerous shell middens across coastal Denmark at the Mesolithic-Neolithic transition using quantitative and qualitative salinity inference from several, independent proxies (diatoms, molluscs and foraminifera) from multiple Danish fjord sites. Alternatively, we attribute the oyster decline to other environmental causes (particularly changing sedimentation), ultimately driven by external climatic forcing. Critical application of such high-quality environmental archives can reinvigorate archaeological debates and can aid in understanding and managing environmental change in increasingly impacted coastal regions.

\section{Introduction}

A striking but consistent feature of many Danish Stone Age shell middens is a high abundance of the European flat oyster (Ostrea edulis), present in Mesolithic (Ertebølle culture) layers, and its widespread replacement about 5,900 cal. yrs BP by species such as the cockle (Cerastoderma edule) and the blue mussel (Mytilus edulis) in the Early Neolithic layers (Funnel Beaker culture) (Andersen, 2000; Fischer and Kristiansen, 2002; Andersen, 
2007). The oyster decline is contemporaneous with the introduction of agriculture in southern Scandinavia (ca. 5,900 cal. yrs BP Andersen and Rasmussen, 1993) and the concomitant transition from a predominately marine to terrestrial diet for humans (Tauber, 1981; Fischer et al., 2007), and has previously been hypothesised to be a casual factor behind these changes (Rowley-Conwy, 1984; Andersen, 2007). Although the oyster decline has been known for almost 50 years (Andersen, 1976), its cause remains contested. Oysters require higher salinities and temperatures than the species which widely replaced it (mainly cockles and mussels) in the Neolithic layers of many Danish shell middens and subsequently several environmental (as opposed to cultural) hypotheses have been proposed for this transition (Rowley-Conwy, 1984; Bailey and Milner, 2008; Schulting, 2010). The most commonly cited hypothesis is the declining salinity of inner, accessible coastal waters (Rowley-Conwy, 1984; Andersen, 2007) perhaps associated with lowering of relative sea-level (Christensen, 1995; Berglund et al., 2005) and/or a reduction in tidal amplitude (Nielsen, 1938; Petersen, 1993; Petersen et al., 2005), both ultimately reducing the input of high-salinity water from the North Sea into the inner Danish coastal waters of the Limfjord and Kattegat. Ostrea edulis generally requires salinities above $23-25 \mathrm{~g} \mathrm{~L}^{-1}$ and summer water temperatures above $15^{\circ} \mathrm{C}$ to spawn successfully (Jensen and Spärck, 1934; Yonge, 1960). In Danish coastal waters today, the European flat oyster is confined to the western part of the Limfjord (which is open to the North Sea in the west) and to the deeper, highly saline and oxic waters of the Kattegat, where the species occurs very sporadically

Here we use palaeoenvironmental data to test the so-called "salinity hypothesis" mentioned above (hereafter $\mathrm{H} 1$ ). We also use palaeoenvironmental data, regional palaeoclimate data and present-day oyster ecology and habitat information to test two other plausible explanations, namely; $(\mathrm{H} 2)$ the temperature decline at the end of the Holocene thermal maximum directly affected oyster reproduction and population dynamics and $(\mathrm{H} 3)$ increased sedimentation altered the availability of suitable habitats. Cultural rejection of oysters as a food, linked to the adoption of agriculture, and/or population increase (Shennan et al., 2013) 
might also provide alternative, non-environmental explanations for the oyster decline $(\mathrm{H} 4)$. We consider this briefly in the discussion but focus upon the three main environmental hypotheses for the oyster decline given above $(\mathrm{H} 1-\mathrm{H} 3)$, as these can be tested directly using palaeoenvironmental data. Here, we apply state-of-the-art multiproxy palaeoenvironmental techniques to reconstruct key environmental parameters (notably salinity and sedimentation change) from Danish fjord sediments collected either adjacent or in close proximity to Stone Age shell middens (Fig. 1A-D) to test competing environmental hypotheses $\mathrm{H} 1-\mathrm{H} 3$ independently and critically.

\section{Methods and results}

Multiproxy palaeoenvironmental analyses (diatoms, molluscs and foraminifera, prepared using standard techniques; see Supplementary Data) were performed on five Holocene sedimentary sequences collected from past (Korup Sø) or present shallow $(<6 \mathrm{~m})$ Danish fjord systems from Jutland and Zealand (Fig. 1A and Table 1). Salinity change was quantitatively reconstructed at each site (Fig. 2A; Table 1) using a 210-site coastal panBaltic diatom-inferred (DI) salinity inference model. Age-depth models were produced for each site based on multiple ${ }^{14} \mathrm{C}$ datings of terrestrial plant material (Kilen, Tempelkrog, Horsens Fjord, Norsminde Fjord) or shell material (Korup Sø). Full methodological details are provided in Supplementary Data.

The DI-salinity reconstructions infer similar or higher salinity levels than at present over both the late Mesolithic and Early Neolithic period (Fig. 2A), but with no evidence for a salinity decline at the Mesolithic/Neolithic transition (5,900 cal. yrs BP) or even persistently lower salinity in the Neolithic period. This is corroborated by qualitative mollusc and foraminiferal assemblage data and novel semi-quantitative mollusc-based minimum salinity reconstructions (MI-salinity, Table 1, Fig. 2A; Supplementary Data) available at four of the five sites (not Norsminde Fjord). The Danish molluscan fauna is particularly well studied and this new semi-quantitative approach makes use of long-term observations, distribution and 
wealth of knowledge of molluscan species-salinity relationships (available in the literature) to

produce a semi-quantitative estimate of the lower-range of salinity required to support the

fauna found in the fossil dataset.

Statistical analysis of DI and MI-salinity values for each sequence confirms this with only a single case out of 9 comparisons with a significant decrease between the Mesolithic and Neolithic sections, and two cases of salinity increase (1-tailed t-test, $p<0.05$; Table 1). Moreover, the MI-minimum salinity decline at Korup Sø is gradual rather than dramatic (contrary to $\mathrm{H} 1$ ), likely reflecting local changes to hydrography at this site rather than a regional salinity change as the connection between the site and the sea gradually disappeared due to isostatic uplift, sedimentation and progressive isolation from the Kattegat. The diatom data supports this interpretation, as there is no decrease in DI-salinity at Korup Sø over this period, despite the gradual switch from planktonic to benthic taxa.

Bulk sediment accumulation rates (AR, Fig. 2B) were calculated for each site using the agedepth models. At Horsens Fjord, Norsminde Fjord and Korup Sø, relatively lower sedimentation rates are recorded in older sediments (i.e. before 6,000 cal. yrs BP). Accumulation rates increase gradually at both Norsminde Fjord and Horsens Fjord from about 6,500 cal. yrs BP, while Korup Sø AR remains low until ca, 5,900 cal. yrs BP, when a three-fold increase occurs. At Tempelkrog, the highest rates occur between ca. 7,000-5,850 cal. yrs BP and decline in the Early Neolithic period. Kilen exhibits a pattern typical of sediment focussing (i.e. movement of sediment from shallower to deeper zones of the fjord), with higher sedimentation rates occurring under deeper water conditions (before ca 7,000 cal. yrs BP), falling as the fjord gets shallower from ca 5,200 cal. yrs BP (Lewis et al., 2013).

\section{Discussion}


The high abundance of coastal shell middens dated to the late Stone Age (from ca. 7,600 ca. yrs BP (Andersen, 2000, 2007) suggests that environmental conditions were optimal for mollusc growth in general at that time, and for oysters in particular. This includes high salinity (> 23-25 $\mathrm{g} \mathrm{L}^{-1}$ to support breeding populations), high summer temperatures $\left(>15^{\circ} \mathrm{C}\right)$ and suitable substrate (Spärck, 1924; Jensen and Spärck, 1934; Yonge, 1960). Our data suggest that suitable salinity conditions extend into the Early Neolithic period (Fig. 2A and Supplementary Data). We observe no evidence of a widespread, sudden decline in salinity at the Mesolithic/Neolithic transition or any period of persistently lower salinity within the Early Neolithic (Fig. 2A), in either the quantitative or qualitative biological data (diatom, foraminiferal and mollusc) presented here. We also discount any role played by changing tidal amplitude on salinity (and sedimentation) dynamics within the Danish coastal waters as recent results from tidal modelling suggest that only minor changes have occurred in the tidal amplitude around the North Sea and Baltic coasts over the last 8,000 years (Uehara et al., 2006). Furthermore, we find no evidence amongst any of the biological proxies (in terms of either inferred salinity change or a shift in assemblage composition to more benthic taxa) for a sudden, substantial sea-level change around 6,100 cal. yrs BP as inferred at Blekinge in southern Sweden (Berglund et al., 2005). Rather, our proxy data are more consistent with the muted sea-level fluctuations reconstructed for eastern Denmark at Vedbæk (Christensen, 2001) (Fig. 2A). We therefore reject the salinity hypothesis $(\mathrm{H} 1)$ as the cause of the oyster decline in the Danish shell middens over the Mesolithic-Neolithic transition.

The other two environmental hypotheses ( $\mathrm{H} 2$ : temperature decline and $\mathrm{H} 3$ : increased sedimentation) need not in fact be mutually exclusive. Here we argue for a more nuanced, spatially complex alternative that combines these two environmental explanations for the oyster decline. The trends within the shell middens (outlined above) and palaeoenvironmental records presented here (Figs. 2) all exhibit a degree of spatial and temporal variability, but provide evidence for extensive changes in the marine environment at, or near 5,900 cal. yrs BP, at a time when climate was beginning to cool (Snowball et al., 
2004; Seppä et al., 2009; Brown et al., 2012) (Fig. 2B). We hypothesise that accessible oyster beds were steadily waning as a resource for hunter-gatherer societies from ca. 6,300 cal. yrs BP, as temperature in particular declined below optimal conditions $(\mathrm{H} 2)$, but other factors (specifically sedimentation patterns) triggered the sudden oyster decline recorded in shell middens.

Suitable habitat is key to the development of oyster beds. Ostrea edulis favours a hard substrate (i.e. coarser silts/sands containing stones and shells) with sparse vegetation cover, and is easily choked by a high flux of fine-grained sediment (Jensen and Spärck, 1934; Yonge, 1960). This contrasts with taxa such as Cerastoderma edule and Mytilus edulis, which are better suited to living in finer sediments (Jensen and Spärck, 1934). Over the Late Mesolithic/Early Neolithic, sedimentation rates increased (i.e. starting before agriculture developed in coastal catchments) at four of the five sites (though earlier at Tempelkrog, beginning around $\sim 6,900$ cal. yrs BP and peaking between ca. 6,400-6,100 cal. yrs BP), increasing the rate of shallowing of these fjords and reducing exchange and sedimentary export (Fig. 2B).

The underlying causes behind increased sedimentation rates in Danish Fjords in the Late Mesolithic/Early Neolithic period need to be investigated further, though it remains likely that these differ between sites for a variety of reasons (as demonstrated by the variable timings in the data presented here; Fig 2b). Individual fjord sedimentation rates are likely to be heavily influenced by topographical features such as fjord area, water depth and watercurrent systems. After several thousand years of sedimentation since being sub-merged by the rising sea levels in the Early Holocene (Petersen, 1981; Christensen, 1995, 2001; Berglund et al., 2005; Bendixen et al., 2015), many of these sites were likely becoming shallower, and increasingly acting as sediment sinks. Shallowing would also promote macrophyte development, further trapping sediments. 
Additionally, changing climate around this time likely also contributed to increased and/or variable sedimentation rates in these fjord systems. Isotope records from regional lake and peat systems show some variability with some records indicating a more humid Holocene thermal maximum (HTM), followed by drier conditions in the Early Neolithic (e.g. Harrison and Digerfeldt, 1993; De Jong et al., 2006; Olsen et al., 2010). Whilst other nearby lakes (e.g. Hammarlund et al., 2003; Seppä et al., 2005) suggest a shift to wetter conditions in southern Scandinavia after ca. 6,100 cal. yrs BP, likely increasing run off and sediment input from the catchment. Changing surface wetness and decreasing temperatures towards the end of the peak period of the HTM (ca. 8,000 BP and 4,000 BP in northern Europe with maximum temperatures between ca. 7,500-6,000 BP; Snowball et al., 2004; Antonsson et al., 2008; Renssen et al., 2012) would have likely influenced the local vegetation and subsequently run off rates and fjord-sedimentary inputs. Later (post ca. 5,900 BP), forest clearance might also have been important following the introduction of agriculture into the catchments (and in some areas forest restructuring following the pathogen-related elm (Ulmus) decline; Andersen and Rasmussen, 1993; Peglar and Birks, 1993; Rasmussen et al., 2002).

Under these combined conditions, a positive feedback between increasing sediment accumulation rate and fjord shallowing might develop, eventually leading to the decline or disappearance of once productive, but increasingly stressed and perhaps over-exploited oyster beds from many shallower, accessible coastal areas. Bailey and Milner (2008) and Nielsen (2008) have both previously suggested that a combination of environmental stress and over-exploitation might be responsible for oyster populations decreasing in size and age (with progressively younger individuals being collected) in Neolithic layers of the Norsminde Fjord and Krabbesholm shell middens (Fig 1A, D). Importantly, whilst the oyster decline was widespread it was not total and oysters remained accessible, and even locally abundant at a few sites, far into the Neolithic period where favourable hydrographic conditions allowed (e.g. at Havnø, Visborg and Krabbesholm, Andersen, 2008; Nielsen, 2008; Figs 1A, C) 
despite declining temperature. This argues against a cultural explanation (or a purely temperature-driven threshold; Fig. 2) for the oyster decline as oysters were clearly not rejected as a dietary component. Shellfish were still harvested in many places, despite the occurrence of a cultural shift from a marine to a terrestrially-dominated diet (Tauber, 1981; Fischer et al., 2007). Indeed some oyster-dominated middens re-appeared briefly in Denmark around 4,900-4,400 cal. yrs BP during the Pitted Ware and Single Grave cultural period, although with far fewer shells (Andersen, 2007). However, forest restructuring following the elm decline and early Neolithic forest clearances resulted in sedimentation rates increasing in many sites across Denmark (at Korup Sø, dramatically so; Fig. 2B), and this marked the end of large-scale oyster harvesting across coastal Denmark.

\section{Lastly, Shennan et al. (2013) also show a distinct increase in human population density}

around 5,900 BP (following the onset of the Neolithic period) in Denmark. Measurement of the size and age of mollusc populations present in shell middens can give an indication of the natural population health and resource exploitation pressure. In Denmark, these analyses have shown only a gradual decrease in age and size of collected oysters present within the middens over time (and continuing throughout the Neolithic) (Bailey and Milner, 2008; Nielsen, 2008) suggesting slow degradation of natural oyster beds, and perhaps more consistent with changing environmental conditions than over-exploitation. Furthermore, Bailey and Milner (2008) have shown that oyster populations at Norsminde Fjord do not appear to have become particularly stressed (i.e. greater collection of smaller and younger specimens) until later in the Neolithic, and much later than the Mesolithic-Neolithic oyster decline. If increasing human population (and subsequent over-exploitation) was a primary cause of the oyster decline, then an initial increase in the abundance of oysters present in the shell middens in the Early Neolithic might be expected, followed by a more rapid shift smaller, younger specimens as the natural oyster populations became more rapidly stressed due to over-exploitation. Whilst, human population increase in the Neolithic (Shennan et al., 2013) likely accentuated this gradual pattern of decreasing age and size of oysters evident in 
Danish shell middens through time (Bailey and Milner, 2008; Nielsen, 2008), the lack of clear evidence for large-scale stress on the shell midden-oyster population at ca. 5,900 BP argues against this as a primary cause of the major oyster decline. However, we acknowledge that age-size data of collected molluscs are not available for all shell middens demonstrating an oyster decline, and therefore in some cases earlier, localised population stress due to increasing population and human impact might have occurred. However, with the data available we argue that changing environmental conditions (lower temperature and increased sedimentation rates) caused an overall decline in oyster availability, particularly in the near-shore more-accessible oyster beds, meaning that alternative resources were exploited (no evidence for stress on alternative resources). Furthermore, as the major oyster decline is generally synchronous across Denmark, then if localised human impacts and population increase were major causes, then greater variability in the timing of this oyster decline might be expected.

\section{Conclusions}

The oyster decline (evident in many Danish shell middens) is seen as an important marker of a wider human resource shift, attributable to environmental and climate change, without the need to invoke purely cultural hypotheses which may be difficult to test rigorously. Specifically, we argue that the change is principally the result of accelerated deposition of fine-grained sediments during a period of declining temperatures, rather than reduced salinity. These factors altered conditions within inner coastal waters, fjord systems and local catchments, e.g. increasing sedimentation rates to levels critical for oyster populations to survive.

We have shown here that palaeoenvironmental data can help establish the context for archaeological inquiry, make important contributions to understanding patterns of archaeological and cultural change, and test competing hypotheses of change. We hope 
that the unequivocal rejection of the long-standing salinity hypothesis based on qualitative and quantitative salinity inferences and our alternative environmental hypothesis will reinvigorate archaeological debate concerning the introduction of agriculture and human subsistence strategies in southern Scandinavia. Furthermore, understanding the impacts that climate and environmental change has on valuable marine resources is critical for successful and sustainable management of heavily exploited ecosystems such as the Baltic Sea in light of projected changes for this system in future.

\section{Acknowledgements}

For data analyses we thank Karin Gutfelt Jensen (diatom analysis at Horsens Fjord), Kaj Strand Petersen (molluscs at all sites), Peter Konradi (foraminifera at Horsens), Peter Kristensen (foraminifera at Kilen), Beth Stavngaard (sediment physical analyses), Aarhus University ${ }^{14} \mathrm{C}$ dating facilities (for all ${ }^{14} \mathrm{C}$ dates), Harald Krog (original coring and pollen analyses from Korup Sø) and additional MOLTEN/DEFINE project members (http://craticula.ncl.ac.uk/Molten/jsp/). We also thank Bent Odgaard and Ole Bennike for field assistance. This work was carried out under funding from the Carlsberg Foundation (ANS1283/20 to DBR), the Danish Council for Independent Research-Natural Sciences and Humanities (grants 21-03-0510 and 25-03-0462 to PR), Loughborough University Development Fund (Ph.D. funding for JPL) and the Geological Survey of Denmark and Greenland (for funding of numerous ${ }^{14} \mathrm{C}$ datings).

\section{References}

Andersen, S.H., 1976. Norsminde Fjord undersøgelsen. En arkæologisk undersøgelse af stenalderbebyggelsen i en østjysk fjord i perioden ca. 4500-1500 f.Kr. med særligt henblik på de kulturelle og erhvervsmæssige forhold, In: Thrane, H. (Ed.), Bebyggelsesarkæologi. Skrifter fra Institut for Historie og Samfundsvidenskab no. 17, Odense Universitet, pp. 18-61. 
Andersen, S.H., 2000. 'Køkkenmøddinger' (shell middens) in Denmark: a survey.

Proceedings of the Prehistoric Society 66, 361-384.

Andersen, S.H., 2007. Shell middens ("Køkkenmøddinger") in Danish Prehistory as a reflection of the marine environment., In: Milner, N., Craig, O.E., Bailey, G.N. (Eds.), Shell Middens in Atlantic Europe. Oxbow Books, Oxford, pp. 31-45.

Andersen, S.H., 2008. A report on recent excavations at the shell middens of Havnø in Denmark. Mesolithic Miscellany 19, 2-5.

Andersen, S.T., Rasmussen, K.L., 1993. Radiocarbon wiggle-dating of elm declines in northwest Denmark and their significance. Vegetation History and Archaeobotany 2, 125135.

Antonsson, K., Chen, D., Seppä, H., 2008. Anticyclonic atmospheric circulation as an analogue for the warm and dry mid-Holocene summer climate in central Scandinavia. Climate of the Past 4, 215-224.

Bailey, G., Milner, N., 2008. Molluscan archives from European prehistory, In: Antczack, A., Cipriani, R. (Eds.), Early Human Impacts on Megamolluscs. BAR International Series, pp. 111-134.

Bendixen, C., Jensen, J.B., Boldreel, L.O., Clausen, O.R., Bennike, O., Seidenkrantz, M.-S., Nyberg, J., Hübscher, C., in press. The Holocene Great Belt connection to the southern Kattegat, Scandinavia: Ancylus Lake drainage and Early Littorina Sea transgression. Boreas. DOI. 10.1111/bor.12154

Berglund, B.E., Sandgren, P., Barnekow, L., Hannon, G., Jiang, H., Skog, G., Yu, S.Y., 2005. Early Holocene history of the Baltic Sea, as reflected in coastal sediments in Blekinge, southeastern Sweden. Quaternary International 130, 111-139. 
Brown, K.J., Seppä, H., Schoups, G., Fausto, R., Rasmussen, P., Birks, H.J.B., 2012. A spatio-temporal reconstruction of Holocene temperature change in southern Scandinavia. The Holocene 22, 165-177.

Christensen, C., 1995. The Littorina transgressions in Denmark, In: Fischer, A. (Ed.), Man and sea in the Mesolithic. Coastal settlement above and below present sea-level. Oxbow Books, Oxford, pp. 15-22.

Christensen, C., 2001. Coastal settlement and sea-level change in the Stone Age., In: Jensen, O.L., Sørensen, S.A., Hansen, K.M. (Eds.), Denmarks Hunting Stone Age - status and perspectives, Hoersholm Egns Museum, pp. 183-193.

Dahl, K., Lundsteen, S., Helmig, S.A., 2003. Stenrev - havets oaser. Gads Forlag, Copenhagen.

De Jong, R., Björck, S., Bjorkman, L., Clemmensen, L.B., 2006. Storminess variation during the last 6500 years as reconstructed from an ombrotrophic peat bog in Halland, southwest Sweden. Journal of Quaternary Science 21, 905-919.

Fischer, A., Kristiansen, K., 2002. The Neolithisation of Denmark. 150 years of debate. J.R.Collis, Sheffield.

Fischer, A., Olsen, J., Richards, M., Heinemeier, J., Sveinbjörnsdóttir, A.E., Bennike, P., 2007. Coast-inland mobility and diet in the Danish Mesolithic and Neolithic: evidence from stable isotope values of humans and dogs. Journal of Archaeological Science 34, 21252150.

Hammarlund, D., Björck, S., Buchardt, B., Israelson, C., Thomsen, C.T., 2003. Rapid hydrological changes during the Holocene revealed by stable isotope records of lacustrine carbonates from Lake Igelsjön, southern Sweden. Quaternary Science Reviews 22, 353370. 
Harrison, S.P., Digerfeldt, G., 1993. European lakes as palaeohydrological and palaeoclimatic indicators. Quaternary Science Reviews 12, 233-248.

Jensen, S., Spärck, R., 1934. Bløddyr II. Saltvandsmuslinger. Danmarks Fauna 40, 208.

Lewis, J.P., Ryves, D.B., Rasmussen, P., Knudsen, K.L., Petersen, K.S., Olsen, J., Leng, M.J., Kristensen, P., McGowan, S., Phillipsen, B., 2013. Environmental change in the Limfjord, Denmark (ca 7,500-1500 cal yrs BP): a multiproxy study. Quaternary Science Reviews 78, 126-140.

Mertz, E.L., 1924. Late and post-glacial height changes in Denmark (In Danish). Danish Geological Survey (DGU) 2. 41, 50.

Nielsen, E.S., 1938. De danske farvandes hydrografi i Litorinatiden. Dansk Geologisk Forening 9, 337-350.

Nielsen, N., 2008. Marine Molluscs in Danish Stone Age Middens: A Case Study on Krabbesholm II, In: Antczak, A., Cipriani, R. (Eds.), Early Human Impact on Megamolluscs. BAR International Series. Hadrian Books Ltd, Banbury, Oxford, UK, pp. 157-167.

Olsen, J., Noe-Nygaard, N., Wolfe, B.B., 2010. Mid- to late-Holocene climate variability and anthropogenic impacts: multi-proxy evidence from Lake Bliden, Denmark. Journal of Paleolimnology 43, 323-343.

Peglar, S.M., Birks, H.J.B., 1993. The mid-Holocene Ulmus fall at Diss Mere, South-East England - disease and human impact? Vegetation History and Archaeobotany 2, 61-68.

Petersen, K.S., 1993. Environmental changes recorded in the Holocene molluscan faunas from Djursland, Denmark. Scripta Geologica Special Issue 2, 359-369.

Petersen, K.-S., 1981. The Holocene marine transgression and its molluscan fauna in the Skagerrak-Limfjord region, Denmark. Special Publications International Association of Sedimentologists 5, 497-503. 
Petersen, K.S., Rasmussen, K.L., Rasmussen, P., von Platen-Hallermund, F., 2005. Main environmental changes since the Weichselian glaciation in the Danish waters between the North Sea and the Baltic Sea as reflected in the molluscan fauna. Quaternary International $133,33-46$

Rasmussen, P., Christensen, K., Møller, J.D., 2002. Elmesyge i geologisk perspektiv. Naturens Verden 1, 36-40.

Rasmussen, P., Petersen, K.S., Ryves, D.B., 2007. Environmental change in Danish marine waters during the Roman Warm Period inferred from mollusc data. Geological Survey of Denmark and Greenland Bulletin 13, 21-24.

Renssen, H., Seppä, H., Crosta, X., Goosse, H., Roche, D.M., 2012. Global characterization of the Holocene Thermal Maximum. Quaternary Science Reviews 48, 7-19.

Rowley-Conwy, P., 1984. The Laziness of the Short-Distance Hunter: The Origins of Agriculture in Western Denmark. Journal of Anthropological Archaeology 3, 300-324.

Schulting, R., 2010. Holocene environmental change and the Mesolithic-Neolithic transition in north-west Europe: revisiting two models. Environmental Archaeology 15, 160-172.

Seppä, H., Hammarlund, D., Antonsson, K., 2005. Low-frequency and high-frequency changes in temperature and effective humidity during the Holocene in south-central Sweden: implicatons for atmospheric and oceanic forcings of climate. Climate Dynamics 25, 285-297.

Seppä, H., Bjune, A.E., Telford, R.J., Birks, H.J.B., Veski, S., 2009. Last nine-thousand years of temperature variability in Northern Europe. Climate of the Past 5, 523-535.

Shennan, S., Downey, S.S., Timpson, A., Edinborough, K., Colledge, S., Kerig, T., Manning, K., Thomas, M.G., 2013. Regional population collapse followed initial agriculture booms in mid-Holocene Europe. Nature Communications 4:2486. 
Snowball, I., Korhola, A., Briffa, K.R., Koç, N., 2004. Holocene climate dynamics in Fennoscandia and the North Atlantic, In: Batterbee, R.W., Gasse, F., Stickely, C.E. (Eds.), Past climate variability through Europe and Africa. Kluwer Academic Publishers, Dordrecht, The Netherlands, pp. 364-397.

Spärck, R., 1924. Undersøgelser over Østersens (Ostrea edulis) Biologi i Limfjorden, særlig med Henblik paa Temperaturens Indflydelse paa Kønsskiftet. Centraltrykkeriet, København.

Tauber, H., 1981. 13C evidence for dietary habits of prehistoric man in Denmark. Nature 292, 332-333.

Uehara, K., Scourse, J.D., Horsburgh, K.J., Lambeck, K., Purcell, A.P., 2006. Tidal evolution of the northwest European shelf seas from the Last Glacial Maximum to the present. Journal of Geophysical Research-Oceans 111, C09025.

Yonge, C.M., 1960. Oysters. Collins, London. 


\section{Table and Figure captions}

Table 1. Proxy summary. Summary of biological proxies analysed over the study period from the five Danish coastal sites (ca. 7,400-5,000 BP), with an assessment of salinity change over the Mesolithic-Neolithic transition (Meso-Neo salinity change). See Supplementary Data for stratigraphic profiles of proxies. Salinity change is inferred using qualitative (diatoms, foraminifera, molluscs), semi-quantitative (mollusc-inferred (MI) minimum salinity inference) and quantitative approaches (diatom-inferred salinity), and is qualified by proxy preservation, and temporal resolution. Molluscs at Norsminde Fjord are too poorly preserved to permit a reliable salinity inference. Individual stratigraphic plots for proxies are shown in Supplementary Data. * = Temporal resolution of MI-min salinity inferences based on amalgamated $10 \mathrm{~cm}$ slices. One-tailed t-tests on Mesolithic and Neolithic data series were applied after testing for unequal variances; $n . s .=$ not significant $(p$ $>0.05)$; values in italics indicate a positive salinity difference between Neolithic and Mesolithic sections (i.e. higher salinity in Neolithic sections).

Fig. 1. A. Map of Denmark and shell midden data. Location of the five study sites, Kilen, Korup Sø, Norsminde Fjord, Horsens Fjord and Tempelkrog and distribution of late coastal Stone Age shells middens across Denmark (shaded areas). Numbered sites 1-5 contain Stone Age shell middens with abundant oysters: 1. Bjørnsholm 2. Ertebølle, 3. Krabbesholm, 4. Visborg, 5. Havnø. Site 6 (Vedbæk) shows the location from which the Danish sea-level curve displayed in Fig. 2A originates. Isolines show the modern surface salinity $\left(\mathrm{g} \mathrm{L}^{-1}\right)$ gradient in the Kattegat and adjacent coastal waters. Isobases for the highest level of the Littorina Sea (ca. 6,200 yrs BP) above present sea-level in Denmark are shown by black dotted lines; in metres (italicised numbers) after Mertz, 1924; Christensen, 2001. Map modified from Dahl et al. (2003) and Rasmussen et al. (2007). B. Photo of a section through the late Stone Age (ca. 6,800-5,500 cal. yrs BP) Norsminde Fjord shell midden (courtesy of S.H. Andersen). C. Percentage abundance of key molluscs present in stratigraphic layers of the Late Stone Age Norsminde Fjord shell midden between ca. 6,500-5,200 cal. yrs 
BP/4,500-3,200 B.C. (from Bailey and Milner, 2008). D. Minimum numbers of individuals (MNI) of key molluscs present in stratigraphic layers of the Late Stone Age Krabbesholm shell midden (from Nielsen, 2008). Numbered sections: a. Mesolithic-Ertebølle oysterdominated layer (ca. 6,800 cal. yrs BP/4800 B.C.); b. marine sand containing both Mesolithic and Neolithic artefacts; c. Early Neolithic Funnel Beaker Culture shell layers (ca. 5,900-5,300 cal. yrs BP/3,950-3,350 B.C.); d. compact ash and shell layer and e. brown earth soil with some shell fragments.

Fig 2. Coastal proxy data. A. Palaeosalinity inferred from diatoms (DI-sal.; blue line) and molluscs (MI-min. sal; brown line) for each site over the study period, along with regional sea-level curves (from Vedbæk, East Zealand, Denmark (Christensen, 2001), and Blekinge, south east Sweden (Berglund et al., 2005)). Dotted reference line refers to the average DIsalinity at each site over for the Ertebølle period (ca. 5,900-7,400 cal. yrs BP). Black arrows indicate modern surface salinity (MSS) at the study sites. The modern surface salinity for Tempelkrog is based on the average for the wider Isefjord (Fig. 1). Kilen is now a semiisolated brackish lake (since 1856) and therefore the MSS is taken from the adjacent Struer Bay (See SF1, Supp. data). Korup Sø has no MSS as it is no longer a fjord system. B. Sediment accumulation rates at the five study sites $(7,400-5,000$ cal. yrs BP) based upon the independent ${ }^{14} \mathrm{C}$ age-depth models and pollen-inferred composite air temperature for Denmark (Brown et al., 2012). Abbreviations of archaeological divisions (after Fischer and Kristiansen, 2002): EN = Early Neolithic (ca.5,900-5,300 cal. yrs BP), MNA = Middle Neolithic A (ca.5,300-4,800 cal. yrs BP). 


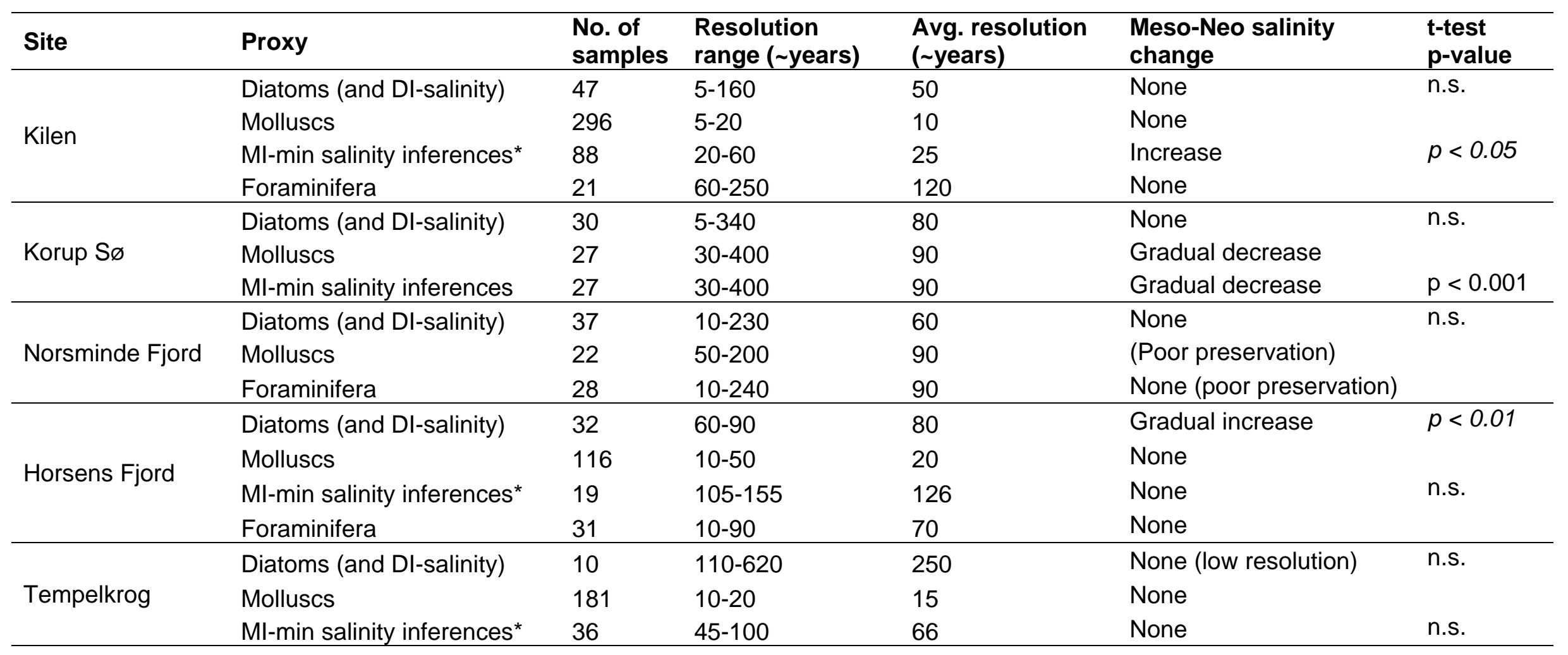




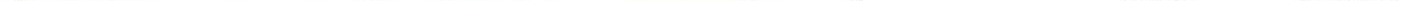




\section{A. Salinity and sea-level}

B. Sediments and temperature

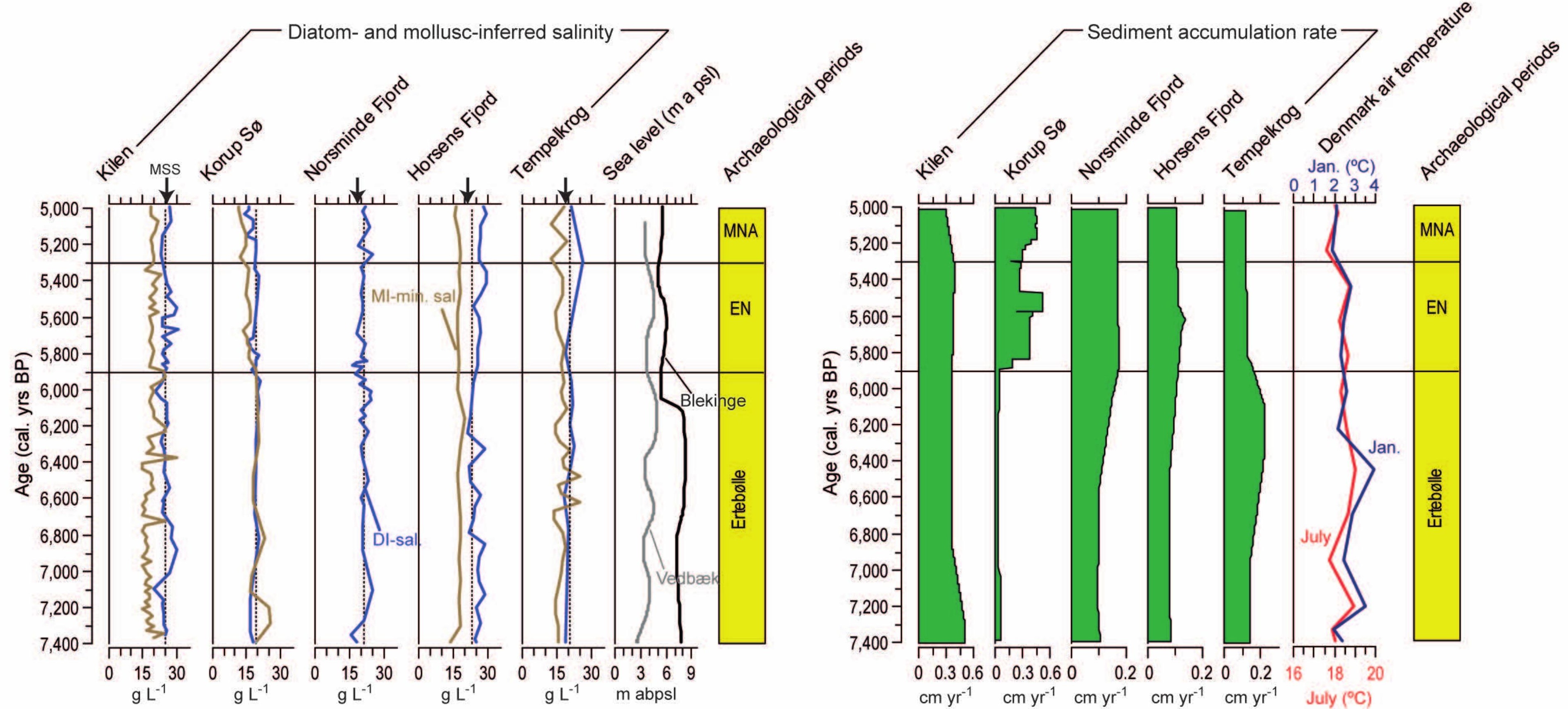

